\title{
Effect of PrP genotype on milk traits in Bovška sheep
}

\author{
MIRAN KASTELIC, SIMON HORVAT and DRAGOMIR KOMPAN \\ Department of Animal Science, Biotechnical Faculty, University of Ljubljana, Domžale, Slovenia
}

\section{Abstract}

The aim of this study was to evaluate the effect of PrP genotype on milk traits in the Slovenian autochthonous Bovška sheep breed. The estimated population size is 3700 animals, half of which are included in the selection programme. Genetic resistance for scrapie, a well known prion disease, is determined by the genotype at the PrP locus. In 2003, the Slovenian National Scrapie Programme following EU Regulations was introduced to control scrapie by selecting out the less resistant genotypes and until 2008, a total of 1875 ewes were genotyped. This study determined frequencies of PrP alleles in Bovška sheep, AHQ 17.32\%, ARH 7.30\%, ARQ 57.14\%, ARR 17.12\% and VRQ 1.12\%, which were very similar to frequencies in other European breeds. The PrP genotype had a significant effect on milk, protein and lactose yield produced in lactation, but the productivity of the most resistant ARR/ARR homozygotes was similar to breed average and did not statistically differ from other genotypes. Heterozygotes AHQ/ARH, AHQ/ARQ and ARH/ARQ exhibited significantly higher productivity compared to respective homozygotes but not from the most resistant ARR/ARR genotype. It is expected therefore that increased frequency of the ARR allele or even its exclusivity will not directly influence the productivity of the breed. However, a careful management programme favouring resistant PrP genotypes should be implemented to reduce potential negative effects of productivity due to reduced selection potential or inbreeding.

Keywords: sheep, Bovška breed, PrP genotype, milk traits

\section{Zusammenfassung}

\section{Einfluss der PrP Genotypen auf Milchmerkmale beim Bovška Schaf}

Untersucht wurden der Einfluss der PrP Genotypen auf Milchmerkmale der bodenständigen Slowenischen Bovška Schafrasse. Der Rassenbestand wird auf 3700 Tiere geschätzt, von denen die Hälfte der Population in das Zuchtprogramm einbezogen ist. Das Slowenische Scrapie National Programm startete 2003 auf der Basis der EU Regelung mit dem Ziel, die nicht resistenten Genotypen zu selektieren. Bis 2008 konnten in dieser Rasse 1875 Mutterschafe genotypisiert werden. Die festgestellten Frequenzen betrugen: AHQ 17,32\%, ARH 7,30\%, ARQ 57,14\%, ARR 17,12\% sowie VRQ 1,12\% und lagen damit ähnlich wie bei anderen europäischen Schafrassen. Der PrP Genotyp hatte einen signifikanten Einfluss auf den Milch-, Eiweiß- und Laktoseertrag. Die Leistungen der meist resistenten ARR/ARR homozygoten Genotypen ähnelten dem Rassendurchschnitt und unterschieden sich nicht signifikant von den anderen Genotypen. Die Heterozygoten AHQ/ARH, AHQ/ARQ und ARH/ARO zeigten signifikant höhere Leistungen im Vergleich zu 
den Homozygoten außer zu ARR/ARR. Es ist zu erwarten, dass die Produktivität der Rasse durch eine höhere Frequenz oder ausschließlich ARR Allelen nicht beeinflusst wird. Für das Zuchtprogramm wird geschlussfolgert, dass bei einer Favorisierung der resistenten Allele vorsichtig zu verfahren ist und Auswirkungen hinsichtlich Produktion oder Inzucht zu beachten sind.

Schlüsselwörter: Schaf, Bovška Rasse, PrP Genotypen, Milchmerkmale

\section{Introduction}

Scrapie is a well known prion disease of sheep, which has occurred in many countries in the past, but not in the South, Central and Eastern European countries including Slovenia. However, recently it has spread into most European countries, including Slovenia. As early as 1962, it was speculated that scrapie was a genetic disorder (PERRY 1962). This hypothesis was later discounted because of observed infectivity of scrapie in sheep (DICKINSON et al. 1974) and transmission of the disease from sheep to goats (BROTHERSTON et al. 1968). However, DICKINSON et al. (1968) did note that some animals could be genetically resistant to scrapie. Nevertheless, it was not until 1995 that BELT et al. (1995) linked this phenomenon to the PrP locus. Five alleles responsible for different levels of susceptibility to scrapie were determined with the VRQ and ARR alleles being the most and least susceptible, respectively. Based on that observation, the European Commission has obligated (2003/100/EC) breeding organizations in the EU to implement selection programme to increase the frequency of ARR allele, and decrease the frequencies of less resistant alleles. However, homozygosity for the resistant ARR allele does not fully protect the animals against the infection and atypical cases of scrapie were also found in ARR homozygotes (LE DUR et al. 2005).

Intensive changing of allele frequencies at the PrP locus can potentially cause some negative consequences. Due to rapid selection for particular PrP genotypes, the genetic variability can be reduced. This may result in reduced selection potential or decreased production due to other negative effects such as inbreeding depression. These indirect negative consequences can be avoided with a well managed selection programme to prevent intensive reduction of less sensitive alleles like ARQ, ARH and AHQ. On the other hand, a direct influence of PrP genotypes on productivity is also possible. The PrP locus can influence productivity due to a linked quantitative trait locus or loci controlling some productivity trait. These linkages can be found in certain populations or breeds only. If the PrP genotype affects a quantitative trait, than the frequencies of PrP alleles are not random because selection changes allele frequencies at the PrP or linked quantitative trait locus.

The frequencies of PrP alleles differ from population to population. The ARQ is the most prevalent allele in most continental breeds ranging between $50.4 \%$ and $75.9 \%$ followed by the ARR allele ranging between $18.2 \%$ and $42.5 \%$ (SALARIS et al. 2007, VAN KAAM et al. 2005, CASELLAS et al. 2006, BRANDSMA et al. 2004, BRANDSMA et al. 2005, DE MARCHI et al. 2005, ALVAREZ et al. 2006, WISNIEWSKA et al. 2006). However, in 7 of 16 breeds of Northern Germany, the ARQ allele was detected at a frequency below $41 \%$ while frequency of the ARR allele was higher than $50 \%$ in 5 of 16 breeds (DRÖGEMÜLLER et al. 2001). 
Frequencies of the most sensitive VRQ allele are generally low in continental breeds ranging between $0.1 \%$ in Sardinian sheep (SALARIS et al. 2007) and up to $8.0 \%$ in the experimental Texel breed (BRANDSMA et al. 2005), with some outliers such as Cameroon sheep reaching a high $95 \%$ (DRÖGEMÜLLER et al. 2001). In comparison with continental breed, British populations differ widely in frequencies at the PrP locus. The ARR allele ranges between 31.1 and $76.5 \%$ (RODEN et al. 2006) and lower frequencies of ARQ compared to ARR allele were found in ten from eleven studied British breeds. An exception was the Scottish Blackface breed (ARQ between 14.3 and $58.9 \%$ ), that also has low VRQ allele frequencies ( 0.3 to $6 \%$ ). Similar frequencies were also found in New Zealand populations (BOSSERS et al. 1999), where the country is free of scrapie despite the fact that the populations originate from Great Britain.

The association studies of PrP alleles with production traits yielded contradictory results. In German black-headed breed, the non-ARR animals were found superior in muscle depth and daily gain (DE VRIES et al. 2003). On the other hand, PrP genotype did not significantly affect any milk trait in the Spanish Churra (ALVAREZ et al. 2006) and in the East Friesian dairy sheep (DE VRIES et al. 2005). However, the ARR homozygotes in Sardinian sheep produced lower milk yields $(P<0.05)$ than ARR heterozygotes or other genotypes (SALARIS et al. 2007). Thus, selection for the resistant ARR alleles could result in negative effects on milk productivity in Sardinian sheep. The PrP genotype did not show any association with reproduction traits in East Friesian dairy sheep (DE VRIES et al. 2005) or in Belclare ewes (SWEENEY et al. 2007). But the ARR/ARR and VRQ/- genotypes were associated with higher fertility in Texel breed (CASELLAS et al. 2007). Likewise, the ARH allele was superior compared to ARR and ARQ alleles in fertility and in weight gain in Ripollesa sheep (CASELLAS et al. 2007). The ARR/ARR genotype showed inferiority and the VRQ allele superiority in the Texel population for weight at 135 days of age (BRANDSMA et al. 2004) and on meat traits in the lle de France, Prealpes du Sud, and Blanc du Massif Central breeds (VITEZICA et al. 2005) with no effects detected in the Texel experimental flock (BRANDSMA et al. 2006). The ARR locus did not influence fattening, meat quality and carcass traits of Thuringian breeds in Germany (GERNAND et al. 2005).

The literature reviewed above shows that quantitative traits are associated with PrP alleles in some but not all populations. Therefore, the consequences of selection for the ARR allele may differ from population to population. This implies that the effects of $\operatorname{PrP}$ genotypes on various productivity traits need to be studied and evaluated separately for each breed or population.

The Bovška sheep (Figure) is a Slovenian autochthonous dairy breed that originates from the Alpine north-western part of Slovenia and is also present at the Italian side of the border. In historical sources they refer to this breed as Krainer Steinschaf that probably originated from Zaupfelschaf (KAVAR et al. 2002). Narrow genetic distance between the Bovška sheep and another Slovenian alpine breed, Jezersko Solčava, suggested close relatedness (KAVAR et al. 2002). The wool of the Bovška breed is rough, mostly white, but can be also brown or black. Animals are of small stature with rams weighing between 45 and 50 and ewes between 35 and $40 \mathrm{~kg}$. The head and ears have fine structure. These small animals are perfectly adapted for the poor conditions on alpine pasture and are efficient milk producers. 


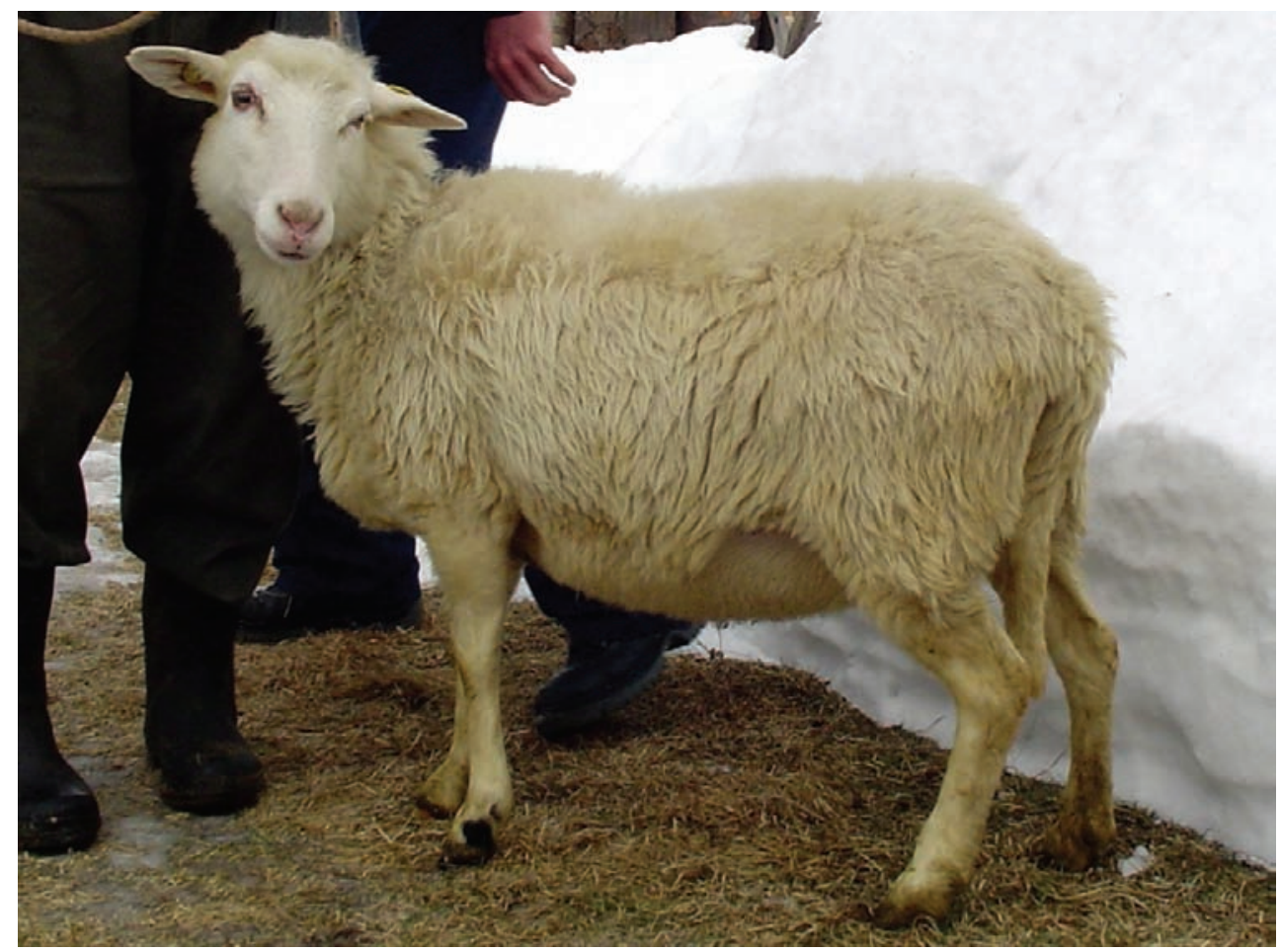

Figure

Bovška sheep breed

Bovška Schaf

\section{Material and methods}

\section{Animals and variables}

Production data used in the present study originated from the Slovenian sheep breeding programme and have been collected since 1994. The estimated population of Bovška breed was 3700 animals in year 2007 (EFABIS 2008). Selection for genetic resistance to scrapie started in the year 2006 and essentially all animals in the selection programme have been included in the genotyping scheme. Data used for this study were from 1878 females genotyped from December 2004 up to April 10th, 2008 (34 in year 2004, 8 in year 2005, 705 in year 2006, 915 in year 2007 and 216 in year 2008). Only females with at least one finished lactation (in total 1568) were included in the statistical evaluation. Genotyped animals present almost half of the whole population. The genotypes were determined using ABI PRISM 7000 apparatus and the allelic discrimination assay.

The productivity of animals was measured according to the AT4 ICAR alternating method. The lactation length was calculated as the period between the lambing date and the date of drying out. Milk yield milked in lactation was calculated according to the following formula: 
$M Y=\frac{\left(I_{0} M_{1}+\frac{I_{1}\left(M_{1}+M_{2}\right)}{2}+\ldots+I_{n} M_{n}\right)}{1000}[\mathrm{~kg}]$

where $M Y$ is the milk yield in $\mathrm{kg}$ in lactation, $I_{0}$ is an interval between the first day of lactation and the first milk recording day, $l_{1}$ is an interval between the previous and the day of the next milk recording date, $I_{n}$ is an interval between the last milk recording day and the day of drying out. $M_{1}$ to $M_{n}$ are the milk quantities, recorded at recording day one to the last recording day in $\mathrm{g}$. The quantity of suckled milk in $\mathrm{kg}$ is estimated as five times the weight gain of a lamb or lambs from birth to weaning, where the birth weight of singles is estimated as $4 \mathrm{~kg}$, and the birth weight of twins as $7 \mathrm{~kg}$ and the birth weight of triplets as $7.5 \mathrm{~kg}$ of live weight. Milk, produced in lactation is estimated as a sum of milk quantity, milked in lactation and milk quantity, suckled by lambs. The percentages of fat, proteins and lactose were analyzed. The percentage of dry matter was estimated as a sum of fat, proteins and lactose percentages. The quantity of fat, milk and lactose, produced in lactation was calculated from percentages and quantities of milk, produced in lactation.

\section{Statistical methods}

Statistical evaluation was done in three steps. In the first step, the frequencies of alleles and genotypes were calculated using SAS/STAT programme (SAS/STAT 2001) using procedure FREQ. The second step estimated average values of production data according to different genotypes by SAS/STAT programme, procedure MEANS. The third step evaluated analysis of variance. As the frequencies of genotypes $V R Q / V R Q, A H Q / V R Q$, $A R R / V R Q, A H Q / A H Q$ and $A R H / A R Q$ were very low, they were excluded from the analysis of variance, and so were flocks with less than 40 known PrP genotypes and animals with lactations shorter than 100 days.

The data set was evaluated with the following statistical model:

$$
Y_{i j k}=\mu+G_{i}+F_{j}+b_{1}\left(T_{i j k}-\bar{T}\right)+\sum_{l=1}^{3} b_{2 l}\left(P_{i j k}-\bar{P}\right)^{\prime}+\sum_{m=1}^{3} b_{3 m}\left(S_{i j k}-\bar{S}\right)^{m}+\sum_{n=1}^{2} b_{4 n}\left(L_{i j k}-\bar{L}\right)^{n}+e_{i j k}
$$

where $Y_{i j k}$ is an observation of the studied trait, $\mu$ is an average of the statistical model, $G_{i}$ is an effect of the $i$-th PrP genotype, $F_{j}$ is an effect of the $j$-th flock ( $j$-th farm), $b_{1}\left(T_{j i k}-\bar{T}\right)$ is a linear regression of year of lactation on a studied trait, $\sum^{3} b_{21}\left(\rho_{p_{k}}-\bar{P}\right)^{\prime}$ is a cubic regression effect of parity on a studied trait, $\sum^{3} b_{s m}\left(s_{\mu k}-\bar{s}\right)^{m}$ is a cubic regression effect of the day of lambing on every single studied trait and presents a seasonal effect, $\sum_{b_{t n}}^{2}\left(L_{k}-L\right)^{n}$ is a quadratic regression of lactation length on studied traits and $e_{i j k}$ is the residual of the observation ijk. The lambings are seasonal and therefore a day of lambing is simply the successive day in the year - January 1st had value 1, February 1st had value 32 etc.

The data were evaluated with SAS/STAT programme, procedure GLM that analyses the Least square means for genotypes. Differences between the expected values of heterozygotes, calculated as average values of two respective homozygotes and established values of heterozygotes (contrasts) were also calculated with the same programme. 


\section{Results}

\section{Frequencies}

Frequencies and percentages of PrP alleles as well as genotypes of Bovška breed are presented in Table 1. The most frequent allele in the Bovška breed is ARQ (57.14\%). The proportion of the resistant ARR (17.12\%) allele was similar to the proportion of the AHQ allele (17.32\%). The proportion of the most sensitive VRQ allele was only $1.22 \%$.The most sensitive genotype VRQ/VRQ was found only in one case $(0.06 \%)$. Only 33 animals out of $1568(2.11 \%)$ were heterozygotes possessing one VRQ allele. Homozygotes for the most resistant genotype ARR/ARR were more frequent (3.89\%), however. More than a quarter of animals (25.98\% or 406 animals) were heterozygotes with one ARR allele, ARR/ARQ, ARR/ARH and ARQ/ARQ.

Table 1

Frequencies (freq) and percentages (\%) of PrP alleles and genotypes of Bovška breed Frequenzen (freq) und Anteile (\%) der PrP Allele und Genotypen der Bovška Schafe

\begin{tabular}{|c|c|c|c|c|c|c|c|}
\hline \multirow[b]{2}{*}{ Allele } & & & \multicolumn{5}{|c|}{ Genotype } \\
\hline & & & $\mathrm{AHQ}$ & ARH & ARQ & ARR & VRQ \\
\hline $\mathrm{AHQ}$ & $\begin{array}{l}\text { freq } \\
\%\end{array}$ & $\begin{array}{l}543 \\
17.32\end{array}$ & $\begin{array}{l}68 \\
4.34\end{array}$ & $\begin{array}{l}33 \\
2.10\end{array}$ & $\begin{array}{l}289 \\
18.43\end{array}$ & $\begin{array}{l}75 \\
4.78\end{array}$ & $\begin{array}{l}10 \\
0.64\end{array}$ \\
\hline ARH & $\begin{array}{l}\text { freq } \\
\%\end{array}$ & $\begin{array}{l}229 \\
7.30\end{array}$ & & $\begin{array}{l}23 \\
1.47\end{array}$ & $\begin{array}{l}112 \\
7.14\end{array}$ & $\begin{array}{l}35 \\
2.23\end{array}$ & $\begin{array}{l}3 \\
0.19\end{array}$ \\
\hline ARQ & $\begin{array}{l}\text { freq } \\
\%\end{array}$ & $\begin{array}{l}1792 \\
57.14\end{array}$ & & & $\begin{array}{l}542 \\
34.57\end{array}$ & $\begin{array}{l}296 \\
18.88\end{array}$ & $\begin{array}{l}11 \\
0.70\end{array}$ \\
\hline ARR & $\begin{array}{l}\text { freq } \\
\%\end{array}$ & $\begin{array}{l}537 \\
17.12\end{array}$ & & & & $\begin{array}{l}61 \\
3.89\end{array}$ & $\begin{array}{l}9 \\
0.57\end{array}$ \\
\hline VRQ & $\begin{array}{l}\text { freq } \\
\%\end{array}$ & $\begin{array}{l}35 \\
1.12\end{array}$ & & & & & $\begin{array}{l}1 \\
0.06\end{array}$ \\
\hline Total & freq & 3136 & & & & & 1568 \\
\hline
\end{tabular}

The effect of PrP genotype on milk production and composition

The results of analysis of variance are presented in Table 2. The coefficients of determination for traits of milk quantity and quantities of milk ingredients range between 0.5793 and 0.6127 and those for milk composition traits between 0.0937 and 0.1629 . Flock, parity and lactation length affected all studied traits significantly with the flock being the most important source of variance. The season of lambing also influenced all traits analysed with the exception of protein percentage. The year of lambing did not exhibit a significant effect on fat, lactose and dry matter percentage.

The PrP genotype was found to be a less important source of variance in the model. However, the significant effect of this source of variation was on milk yield $(P=0.0190)$ and consequently on the yields of proteins and lactose produced in entire lactation. The yield of fat produced in lactation was not influenced by the genotype, neither were the concentrations of milk components with an exception of fat percentage. 
Table 2

Analysis of variance for milk yield, the yield of milk components in lactation and milk composition Varianzanalyse der erfassten Milchmerkmale

\begin{tabular}{lcrrrrrr}
\hline Trait & Genotype & Flock & Season & Parity & Lact. length & \multicolumn{1}{c}{ Year } & $R^{2}$ \\
\hline Milk, kg & $0.0190^{*}$ & $<0.0001$ & $<0.0001$ & $<0.0001$ & $<0.0001$ & $<0.0001$ & 0.6074 \\
Proteins, kg & 0.0339 & $<0.0001$ & $<0.0001$ & $<0.0001$ & $<0.0001$ & 0.0011 & 0.6127 \\
Fat, kg & 0.0965 & $<0.0001$ & $<0.0001$ & 0.0001 & $<0.0001$ & $<0.0001$ & 0.5821 \\
Lactose, kg & 0.0171 & $<0.0001$ & $<0.0001$ & 0.0001 & $<0.0001$ & $<0.0001$ & 0.5793 \\
Proteins, \% & 0.1203 & 0.0001 & 0.8466 & $<0.0001$ & $<0.0001$ & $<0.0001$ & 0.1286 \\
Fat, \% & 0.0098 & $<0.0001$ & 0.0032 & 0.0387 & $<0.0001$ & 0.1592 & 0.1629 \\
Lactose, \% & 0.6940 & $<0.0001$ & 0.0136 & $<0.0001$ & $<0.0001$ & 0.7834 & 0.0946 \\
Dry matter, \% & 0.1559 & $<0.0001$ & 0.0223 & 0.0003 & $<0.0001$ & 0.2119 & 0.0937 \\
\hline
\end{tabular}

* numbers represent probabilities, $\mathrm{R}^{2}$ coefficient of determination of the model

Comparisons between genotypes revealed that the largest quantities of milk among homozygotes were produced by the ARR/ARR animals (Table 3), but the differences to other genotypes were not significant $(P>0.05)$. The least productive were homozygotes $\mathrm{ARH} / \mathrm{ARH}$ (210.5 kg in lactation); but because of the large standard error of that genotype, it was significantly different $(P<0.05)$ only when compared to the most productive heterozygous animals AHQ/ARH (222.7 kg in lactation), which also produced significantly $(P<0.05)$ more milk than ARQ/ARQ $(210.5 \mathrm{~kg})$ and ARR/ARQ $(210.9 \mathrm{~kg})$ genotypes. The quantities of proteins and lactose produced per lactation were directly dependent on milk quantity because, with the exception of fat content, the genotype had no influence on the concentration of milk ingredients. Differences among genotypes in protein and lactose yield show similar results as for milk yield. The percentage of milk fat was influenced by the PrP genotype, but the milk yield cancelled out that effect on fat yield and therefore PrP genotype had no significant effect on fat yield.

Comparisons between heterozygotes and their respective homozygotes (Table 4) showed that $\mathrm{AHQ} / \mathrm{ARH}$ produced significantly $(P<0.05)$ more milk $(+14.19 \mathrm{~kg}$ per lactation), proteins $(+0.75 \mathrm{~kg}$ per lactation) and lactose $(+0.73)$ than the average of homozygotes ARH/ARH and AHQ/AHQ. Similarly, heterozygotes AHQ/ARQ (+6.94 kg milk, $+0.38 \mathrm{~kg}$ fat and $+0.36 \mathrm{~kg}$ lactose) and heterozygotes ARH/ARQ ( $+9.15 \mathrm{~kg}$ milk and $+0.48 \mathrm{~kg}$ lactose) were superior $(P<0.05)$ to their respective homozygotes AHQ/AHQ, ARQ/ARQ and ARH/ARH. However, the production of heterozygous genotypes ARR/ARH, ARR/ARH and ARR/ARQ was not statistically different from the average values of both homozygotes. In the total fat production and milk composition traits (protein, fat, lactose and dry matter percentage), heterozygous animals did not deviate from their respective homozygotes (Table 4) with the exception of heterozygote $A R R / A R Q$, which produced milk with significantly higher fat\% (+0.119\%) than ARR/ARR and ARQ/ARQ. However, the total fat produced per lactation by this heterozygote did not deviate from the average value of homozygotes, most likely because of its lower production of milk in lactation (-3.87).

\section{Discussion}

The Bovška sheep is a Slovenian autochthonous dairy sheep breed with no recorded incidence of scrapie disease. As the risk for scrapie infection has increased in recent years, 


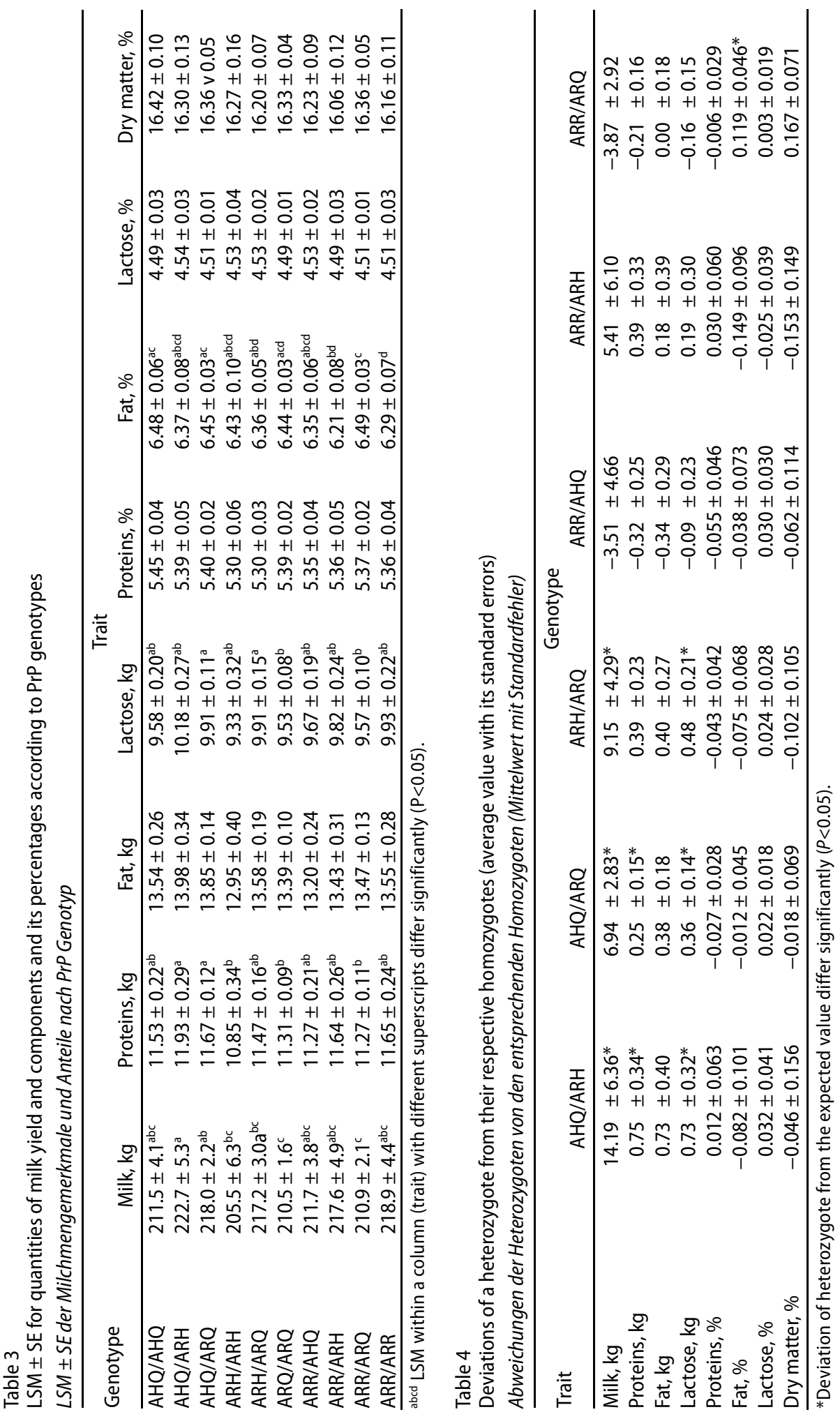


a programme for increasing genetic resistance was initiated in Europe. As such a selection programme can potentially have negative effects on certain production traits in particular breeds, we aimed here to determine the frequencies of PrP alleles and genotypes in Bovška sheep and evaluate their possible associations with milk production and composition traits.

The frequency of the most frequent allele ARQ $(57.14 \%)$ is comparable with the frequencies found in other continental breeds (SALARIS et al. 2007, VAN KAAM et al. 2005, CASELLAS et al. 2006, WISNIEWSKA et al. 2006), although higher proportion of ARQ allele was found in the neighbouring Italian province Veneto (68.0\%, DE MARCHI et al. 2005), in the Spanish Churra sheep (75.9\%, ALVAREZ et al. 2006) and certain Northern German breeds (DRÖGEMÜLLER et al. 2001). The proportions of the desired ARR allele found in other continental breeds were mostly higher than in Bovška sheep (17.12\%), from 18.2\% in the Spanish Churra sheep (ALVAREZ et al. 2006) to $42.5 \%$ in the Sardinian sheep (SALARIS et al. 2007). However, the present study determined that the Bovška breed has among the lowest frequency of the susceptible VRQ allele (1.22\%) reported, which can be viewed as an advantage for this breed. Higher frequencies of the VRQ allele were found in the Texel population (2 to $3 \%$, BRANDSMA et al. 2004), in the Ripollesa breed (3\%, CASELLAS et al. 2006) and in sheep from the Italian province Veneto $5.0 \%$, DE MARCHI et al. 2005). However, these somewhat increased frequencies of more susceptible alleles are still much lower than those found in British breeds (RODEN et al. 2006).

Because of such a low proportion of the VRQ allele and a relatively low proportion of resistant ARR alleles (3.89\% ARR/ARR homozygotes), Bovška sheep can be considered as an intermediately resistant breed to scrapie. The infection of Bovška sheep with scrapie could potentially threaten the breed and therefore increasing the ARR allele proportion could be beneficial.

The PrP genotype had a significant effect $(P<0.05)$ on milk yield, protein yield and lactose yield per lactation. Yield of milk fat per lactation was not affected by the genotype, but the milk fat concentration was. However, PrP genotype had no significant $(P>0.05)$ effect on the concentrations of proteins, lactose and total dry matter. Differences between the PrP genotypes in quantities of proteins and lactose were a consequence of differences in milk quantities produced per lactation and not the consequence of differences in concentrations of these two components. Furthermore, different yields of milk, produced by the different genotypes did not result in differences in total fat produced per lactation because of the effect of PrP genotype on fat concentration.

Hence the PrP genotype had a significant effect $(P<0.05)$ on some productivity traits of Bovška sheep. The ARR/ARR were most productive among the studied homozygotes but the difference was statistically significant $(P<0.05)$ only in comparison to ARH/ARH in milk and protein yield. Some heterozygotes showed better production results in milk yield, protein yield and lactose yield, compared to other genotypes. The most frequent homozygous genotype $A R Q / A R Q$ produces less milk and proteins per lactation than some more productive heterozygotes, which implies a heterosis effect. For example, heterozygotes $\mathrm{AHQ} / \mathrm{ARH}$ produced significantly more proteins $(P<0.05)$ per lactation than homozygotes $\mathrm{AHQ} / \mathrm{AHQ}$ and $\mathrm{ARH} / \mathrm{ARH}$, and heterozygotes $\mathrm{AHQ} / \mathrm{ARQ}$ significantly $(P<0.05)$ more milk fat than was expected from production of homozygotes $\mathrm{AHQ} / \mathrm{AHQ}$ 
and $A R Q / A R Q$. A similar pattern was found for lactose quantity per lactation, where homozygotes generally produced less lactose than heterozygotes.

The productivity of the most desired genotype ARR/ARR did not differ significantly $(P>0.05)$ to other genotypes. It can therefore be expected that selection for resistant ARR alleles will not have an important direct negative effect on productivity of Bovška sheep population as has also been found in Sardinian sheep (SALARIS et al. 2007). The present study therefore suggests that moderate selection on genetic resistance to scrapie in Bovška sheep will most likely be beneficial without undesired consequences on milk production and composition traits. The productivity of the ARR homozygotes in this breed is at least at the same level as the productivity of the other genotypes. Also, the frequency of ARR is high enough to allow efficient simultaneous selection on genetic resistance against scrapie and for increased productivity. A relatively high frequency of the ARR allele also enables moderate selection pressure at the PrP locus that can, in turn, reduce potential negative effects of productivity due to reduced selection potential or inbreeding.

\section{Acknowledgements}

We acknowledge the financial contribution of the following Slovenian institutions: Food Safety Directorate at Ministry of Agricultural, Forestry and Food and Veterinary Administration of the Republic of Slovenia. We are also grateful to Marko Cotman from the Veterinarian Faculty at University of Ljubljana for genotyping.

\section{References}

Alvarez L, Gutierrez-Gill B, San Primitivo F, De la Fuente LF, Arranz JJ (2006) Influence of prion protein genotypes on milk production traits in Spanish Churra sheep. J Dairy Sci 89, 1784-91

Belt PB, Muileman IH, Schreuder BEC, Ruijter JB, Gielkens AL, Smits MA (1995) Indentification of five allelic variants of the sheep PrP gene and their association with natural scrapie. J Gen Virol 76, 509-17

Bossers A, Harsders FL, Smits MA (1999) PrP genotype frequencies of the most dominant sheep breed in a country free from scrapie. Arch Virol 144, 829-34

Brandsma JH, Janss LLG, Visscher AH (2004) Association between PrP genotypes and litter size and 135 days weight in Texel sheep. Livest Prod Sci 85, 59-64

Brandsma JH, Janss LLG, Visscher AH (2005) Association between PrP genotypes and performance traits in an experimental Dutch Texel herd. Livest Prod Sci 95, 89-94

Brotherston JG, Renwick CC, Stamp JT, Zlotnik I (1968) Spread of scrapie by contact to goats and sheep. J Comp Pathol 78, 9-17

Casellas J, Caja G, Bach R, Francino O, Piedrafita J (2007) Association analyses between the prion protein locus and reproductive and lamb weight traits Ripollesa sheep. J Anim Sci 85, 592-7

De Marchi M, Targhetta C, Zanon V, Bondesan V, Schiavon E, Pastore E (2005) Study on PrP locus in four Veneto sheep breeds. Ital J Anim Sci 4 Suppl 2, 128 (Abstr)

De Vries F, Borchers N, Drögemüller C, Hamann H, Reinecke S, Lüpping W, Distl O (2003) Analysis of associations between the Prion Protein genotype and performance traits in different meat sheep breeds. Züchtungsk 75, 259-73 [in German]

De Vries F, Hamann H, Drögemüller C, Ganter N, Distl O (2005) Analysis of associations between the prion protein genotypes and production traits in East Friesian milk sheep. J Dairy Sci 88, 392-8

Dickinson AG, Stamp JT, Renwick CC (1974) Maternal and lateral transmission of scrapie in sheep. J Comp Pathol 84, 19-25

Dickinson AG, Stamp JT, Renwick CC, Rennie JC (1968) Some factors controlling the incidence of scrapie in Cheviot sheep injected with a Cheviot-passaged scrapie agent. J Comp Pathol 78, 313-21 
Drögemüller C, Leeb T, Distl O (2001) Breeding for resistance to scrapie: Detection of polymorphisms in the prion gene in German sheep breeds. Arch Tierz 44 Special Issue, 280-7

EFABIS (2008) Breeds: Breeds by species and country: Slovenia Sheep (bovška ovca). http://efabis.tzv.fal.de [last accessed 01.06.2008]

European Commision (2003) 2003/100/EC Commission Decision laying down minimum requirements of the establishment of breeding programs for resistence to transmissible spongiform encephalopaties in sheep. Off J L 041, 41-5

Gernand E, Lenz H, Moog U, Waßmuth R (2005) Association between prion - protein - haplotypes and yield traits of station and field tested sheep. Arch Tierz 48, 383-95 [in German]

Kavar, T, Kompan, D, Dovč, P (2002) Genetic differentiation among Istrian Pramenka, Bovška sheep and Jezersko-solčavska sheep Zbornik Biotehniške fakultete Univerze v Ljubljani 80, 193-202 [in Slovenian]

Le Dur A, Beringue V, Androeletti O, Reine F, Lai TH, Baron T, Bratberg B, Vilotte JL, Sarradin P, Benestrand SL, Laude $H$ (2005) A newly indentified type of scrapie agent can naturally infect sheep with resistant PrP genotypes. Proc Natl Acad Sci USA 102, 16031-6

Parry HB (1962) Scrapie: a transmissible and hereditary disease of sheep. Heredity 17, 75-105

Roden JA, Nieuwhof GJ, Bishop SC, Jones DA, Haresign W, Gubbins S (2006) Breeding programmes for TSE resistance in British sheep I Assessing the impact on prion protein (PrP) genotype frequencies. Prev Vet Med 73, 1-16

Salaris S, Casu S, Carta A (2007) Investigating the relationship between the prion protein locus and udder morphology traits and milk yield in Sardinian sheep. J Anim Sci 85, 2840-5

SAS/STAT (2001) SAS/STAT User's guide, SAS Institute Inc, Cary NC, USA

Sweeney T, Hanrahan JP, O'Doherty E (2007) Is there a relationship between prion genotype and ovulation rate and litter size in sheep? Anim Reprod Sci 101, 153-7

Van Kaam JBCM, Vitale M, Portolano B, Vitale F, Caracappa S (2005) Preliminary allele frequencies for the PrP gene of Valle del Belice pilot farms. Ital J Anim Sci 4 Suppl 2, 129 (Abstr)

Vitezica ZG, Moreno CR, Bodin L, Francois D, Barillet F, Brunel JC, Elsen JM (2006) No associations between PrP genotypes and reproduction traits in INRA 401 sheep. J Anim Sci 84, 1317-22

Vitezica, ZG, Moreno CR, Bouix J, Barillet F, Perret G, Elsen JM (2005) A study on associations between PrP genotypes and meat traits in French sheep breeds. Anim Sci 81, 325-30

Wiśniewska E, Lühken G, Mroczkowski S, Erhardt G (2001) Prion protein (PrP) gene polymorphisms and breeding for resistance to scrapie in Polish Merino sheep. Arch Tierz 49 Special Issue, 365-71

Received 1 April 2009, accepted 16 December 2009.

Corresponding author:

MIRAN KASTELIC

email: miran.kastelic@bf.uni-lj.si

Department of Animal Science, Biotechnical Faculty, University of Ljubljana, Groblje 3, SI 1230 Domžale, Slovenia 